\title{
Ayurvedic Panchkarma Management of Sthaulya (Obesity): A Case Report
}

\author{
Case Report
}

\author{
Nirmal P Alodaria ${ }^{1^{*}}$, Gupta $\mathrm{SN}^{2}$, Dhaval Dholakiya ${ }^{3}$, Kaushik B Vyas ${ }^{4}$ \\ 1. Lecturer, Department of Roga-vigyan vikriti vigyan, \\ 2. Professor and HOD; 3. Lecturer, Department of Kaychikytsa, \\ 4. Lecturer, Department of Shalya, \\ J.S. Ayurveda mahavidyalaya, Nadiad.
}

\begin{abstract}
Obesity is burning health problem for society nowadays. In Charak Samhita, Sthaulya is described widely and with deep interpretation. Also in sutrasthana which is most important part of Charak Samhita, in different adhyaya (eg. Astauninditiya, Langhanabrumhaniya, Santarpaniya) causes, symptoms and treatment are described. As an alternative approach, Ayurvedic treatment may serve as promising modality.

A 27 years old male patient came in P.D. Patel Ayurveda Hospital at $5^{\text {th }}$ June 2015. Patient measured weight was $98.1 \mathrm{~kg}$ and BMI was 33.94 which is fairly included in obesity category according to NHI guidelines. $\mathrm{He}$ also had some associated complaints like exertional dyspnoea, increased appetite, excessive perspiration. He was admitted in hospital and was treated with Snehana (Aabhyantara and Bahya), Swedana,Vamana, Virechana, Niruha Basti, Udavrtana along with oral medicines like Varunaadi Kwatha, Arogyavardhini Vati, Triphala Guggulu, Kaishor Guggulu and Navayasa Lauha. Also patient was advised to follow prescribed dietary regimes and life style strictly. The patient responded very well. He lost about $10.2 \mathrm{~kg}$ of weight, which was $87.9 \mathrm{kgs}$ and BMI was 30.41 only in 26 days without any complications and any signs and symptoms of malnutrition. So with the help of Ayurvedic management patient got weight loss significantly.
\end{abstract}

Keywords: A case study, Obesity, BMI, Metabolic syndrome, Varunadi kwatha, Arogyavardhini vati.

\section{Introduction}

Obesity is a medical condition in which excess body fat has accumulated to the extent that it may have an adverse effect on health. It is defined by body mass index $(\mathrm{BMI})(1)$. Obesity is one of the leading preventable causes of death worldwide(2). Obesity increases the risk of many physical and mental conditions. These co-morbidities are most commonly shown in metabolic syndrome, a combination of medical disorders which includes: diabetes mellitus type 2, high blood pressure, high blood cholesterol, and high triglyceride levels(3). According to "The Hindu" 2007-10-12,"India facing obesity epidemic: experts", Obesity in India has reached epidemic proportions in the 21 st century, with morbid obesity affecting $5 \%$ of the country's population. Due to genetic tendency of Indians towards abdominal obesity and its associated risk of related lifestyle diseases like Diabetes \& Heart Disease, Ministry of Health \& Family Welfare along with the Indian Council of Medical Research released updated guidelines in 2012 and according to that, Normal BMI : 18.0 - $22.9 \mathrm{~kg} / \mathrm{m}^{2}$, Overweight : 23.0 -

\section{*Corresponding Author:}

\section{Nirmal P. Alodaria}

Lecturer, Department of Roga-vigyan Vikriti Vigyan, J.S. Ayurveda Mahavidyalaya, Nadiad .

E-mail ID: dr.nirmalalodaria@gmail.com
$24.9 \mathrm{~kg} / \mathrm{m}^{2}$, Obesity : > $25 \mathrm{~kg} / \mathrm{m}^{2}$. The World Health Organization (WHO) predicts that overweight and obesity may soon replace more traditional public health concerns such as under nutrition and infectious diseases as the most significant cause of poor health(4).

\section{A Case Study}

We are presenting a case of 27 years old male patient. He came to our OPD on $5^{\text {th }}$ June 2016 and diagnosed as patient of obesity. He was not suffering from any other underlying systemic pathology. Family history of the patient was negative for obesity. The patient presented with symptoms like Weight gain with gradual onset since 3 years, exertional dysponea and excessive perspiration. As per Charak Samhita, symptoms like Bhar vriddhi (weight gain), Chalasphik Udara Stana (excessive movements of abdomen, breast and gluteal region), Ati Kshuhudha (excessive appetite), Ati Pipasa(excessive thirst), Swedabadha (excessive perspiration), Daurbalya (weakness) were found. On examination as objective criteria, his weight was 98.1 $\mathrm{kgs}$ and BMI was 33.94. He was also analysed with body fat analyzer at every follow up. So, on the basis of modern and classical symptomatology, through examination and tests he was diagnosed as a patient of grade - 1obesity (Sthaulya). He did not take any medicine previously for obesity. We started his Ayurvedic treatment as follows: 


\section{Treatment Plan:}

Table No 1: Treatment modality

\begin{tabular}{|c|c|c|c|}
\hline Sl.no & $\begin{array}{l}\text { Treatment } \\
\text { Modality }\end{array}$ & Days & Specifications \\
\hline 1 & $\begin{array}{l}\text { Snehapana } \\
\text { (As poorvakarma of } \\
\text { Vamana) }\end{array}$ & $1^{\text {st }}$ day to $3^{\text {ed }}$ day & $\begin{array}{l}\text { Till tail was started with } 40 \mathrm{ml} \text { twice a day which } \\
\text { gradually increased up to } 70 \mathrm{ml} \text { twice a day on } 3^{\text {ed }} \\
\text { day. }\end{array}$ \\
\hline 2 & $\begin{array}{l}\text { Sarvanga Abhyanga } \\
\& \text { Baspa Swedana }\end{array}$ & $4^{\text {th }}$ day to $5^{\text {th }}$ day & $\begin{array}{l}\text { Sarvaanga Abhyanga with Narayana Tail and } \\
\text { Sarvang Baspa swedana of Nirgundi Patra were done } \\
\text { for } 2 \text { days. }\end{array}$ \\
\hline 3 & Vamana & On $5^{\text {th }}$ day & $\begin{array}{l}\text { Madanafala Choorna - } 3.5 \text { gm with Madhu was used } \\
\text { for Vamanakarma. }\end{array}$ \\
\hline 4 & Rest & On $6^{\text {th }}$ and $7^{\text {th }}$ day & $\begin{array}{l}\text { No any internal medicines were given or procedures } \\
\text { were performed. Patient was prescribed modified } \\
\text { Sansarjana Krama. }\end{array}$ \\
\hline 5. & $\begin{array}{l}\text { Snehapana } \\
\text { (As poorvakarma of } \\
\text { Virechana). }\end{array}$ & $8^{\text {th }}$ day to $10^{\text {th }}$ day & $\begin{array}{l}\text { Till tail again started with } 40 \mathrm{ml} \text { twice a day from } 8^{\text {th }} \\
\text { day which gradually increased up to } 70 \mathrm{ml} \text { twice a } \\
\text { day on } 10^{\text {th }} \text { day. }\end{array}$ \\
\hline 6. & $\begin{array}{l}\text { Sarvanga Abhyanga } \\
\& \text { Baspa Swedana. }\end{array}$ & $11^{\text {th }}$ day to $13^{\text {th }}$ day & $\begin{array}{l}\text { Sarvaanga Abhyanga with Narayana Tail and } \\
\text { Sarvang Baspa swedana of Nirgundi Patra were done } \\
\text { for } 3 \text { days. }\end{array}$ \\
\hline 5 & Virechana & On $13^{\text {th }}$ day & $\begin{array}{l}\text { Virechana karma done with } \\
\text { By Eranda sneha }-30 \mathrm{ml} \text { with } \\
\text { Dindayala choorna }-4 \mathrm{gm} .\end{array}$ \\
\hline 6 & Rest & On $14^{\text {th }}$ day & $\begin{array}{l}\text { No any internal or external medicines were given or } \\
\text { procedures were performed. }\end{array}$ \\
\hline 7 & Oral Medicine & $\begin{array}{l}\text { From } 15^{\text {th }} \text { day to } \\
26^{\text {th }} \text { day }\end{array}$ & $\begin{array}{l}\text { Varunadi kwatha - } 40 \mathrm{ml} \text { BID empty stomach. } \\
\text { Triphala guggulu vati }-3 \text { tabs. TID before meal/ } \\
\text { snacks. } \\
\text { Kaishaur Guggulu tab - } 3 \text { tabs. tab. TID before meal/ } \\
\text { snacks. }\end{array}$ \\
\hline 8 & $\begin{array}{l}\text { Sarvanga } \\
\text { Udavartana }\end{array}$ & $\begin{array}{l}\text { From } 15^{\text {th }} \text { day to } \\
26^{\text {th }} \text { day }\end{array}$ & $\begin{array}{l}\text { From } 15^{\text {th }} \text { day of admission, patient was stared } \\
\text { Udavartana by Aamalaki }+ \text { Lodhra choorna for } 30 \\
\text { min. followed by Sarvang Baspa swedan of Nirgundi } \\
\text { Patra till the discharge i. e. for } 12 \text { days. }\end{array}$ \\
\hline 9 & $\begin{array}{ll}\text { Sarvanga } & \text { Baspa } \\
\text { Swedana } & \end{array}$ & $\begin{array}{l}\text { From } 15^{\text {th }} \text { day to } \\
26^{\text {th }} \text { day }\end{array}$ & $\begin{array}{l}\text { Sarvanga Baspa Swedan of Nirgundi Patra was given } \\
\text { before Sarvanga Udavartana. }\end{array}$ \\
\hline 10 & Oral Medicine & $\begin{array}{l}\text { From } 16^{\text {th }} \text { day to } \\
26^{\text {th }} \text { day }\end{array}$ & $\begin{array}{l}\text { Arogyavardhini vati } \\
2 \text { tabs TID before meal/snacks. }\end{array}$ \\
\hline 11 & Niruhabasti & $\begin{array}{l}\text { From } 16^{\text {th }} \text { day to } \\
25^{\text {th }} \text { day }\end{array}$ & $\begin{array}{l}\text { From } 15^{\text {th }} \text { day of admission, patient was given Niruha } \\
\text { Basti prepared with Trifala Kwatha } 350 \mathrm{ml} \text { a day till } \\
\text { the day before discharge i. e. for } 10 \text { days. }\end{array}$ \\
\hline 12 & Oral Medicine & $\begin{array}{l}\text { From } 19^{\text {th }} \text { day to } \\
26^{\text {th }} \text { day }\end{array}$ & $\begin{array}{l}\text { Navayasa Lauha } \\
2 \text { gm BD before meal/ snacks. }\end{array}$ \\
\hline
\end{tabular}

\section{Interventions}

Diet : As patient was treated on IPD base so, patient was advised to have boiled Munga (green gram) and boiled vegetables in diet throughout course.

\section{Exercises}

1. Morning and evening fast walk for $3 \mathrm{kms}$

2. Kapalbhati pranayama - 300 round (Divided in 6 parts)

3. Yogasana-

- Pascimotanasana (in form of stretching exercises - 200 times in 4 sets).

- Uttanpadasana (maintain the leg at 30, 45, 90 degree for 5 seconds, 3 sets of 15 times with either leg followed by both leg ). 
Table-2 Signs and symptoms

\begin{tabular}{|c|c|c|c|c|c|c|c|}
\hline $\begin{array}{l}\text { Sl. } \\
\text { No. }\end{array}$ & Signs and symptoms & $\begin{array}{c}\text { Initials } \\
\text { (On first } \\
\text { visit) } \\
05 / 06 / 15 \\
{ }^{*} \text { BT }\end{array}$ & $\begin{array}{c}1^{\text {st }} \text { follow } \\
\operatorname{up}_{12 / 06 / 15}\end{array}$ & $\begin{array}{c}2^{\text {nd }} \\
\text { follow } \\
\operatorname{up}_{19 / 06 / 15}\end{array}$ & $\begin{array}{c}3^{\text {rd follow }} \\
\operatorname{up}_{23 / 06 / 15}\end{array}$ & $\begin{array}{l}4^{\text {th }} \text { follow } \\
\operatorname{up}_{26 / 06 / 15}\end{array}$ & $\begin{array}{c}5^{\text {th }} \text { follow } \\
\operatorname{up}_{29 / 06 / 15} \\
* * A T\end{array}$ \\
\hline 1 & $\begin{array}{l}\text { Exertional dysponea } \\
\text { (Aayase swaskastataa) }\end{array}$ & ++++ & +++ & +++ & ++ & ++ & + \\
\hline 2 & $\begin{array}{l}\text { Excessive Perspiration } \\
(\text { Swdabadha) }\end{array}$ & +++ & ++ & + & + & - & - \\
\hline 3 & Weakness (Daurbalya) & ++ & + & + & + & - & - \\
\hline 4 & $\begin{array}{l}\text { Polydipsia } \\
\text { (Ati Pipasa) }\end{array}$ & +++ & ++ & ++ & ++ & ++ & + \\
\hline 5 & $\begin{array}{l}\text { Polyphagia } \\
\text { (Ati kshudha) }\end{array}$ & +++ & ++ & ++ & + & + & + \\
\hline
\end{tabular}

Note: $(++++)$ - severe presentation of symptom

$(+++)$ - Moderate presentation of symptom

$(++)$ - Mild presentation of symptom

$(+)$ - Least / sometimes presentation of symptom

Table-3: Tests and Clinical examinations

\begin{tabular}{|c|c|c|c|c|c|c|c|}
\hline $\begin{array}{l}\text { Sl. } \\
\text { No. }\end{array}$ & $\begin{array}{l}\text { Tests and clinical } \\
\text { examinations }\end{array}$ & $\begin{array}{c}\text { Initials (On } \\
\text { first visit) } \\
05 / 06 / 15 \\
\text { *BT }\end{array}$ & $\begin{array}{l}1^{\text {st }} \text { follow } \\
\operatorname{up}_{12 / 06 / 15}\end{array}$ & $\begin{array}{c}2^{\text {nd }} \text { follow } \\
\text { up }_{19 / 06 / 15}\end{array}$ & $\begin{array}{c}3^{\text {rd }} \text { follow } \\
\text { up }_{23 / 06 / 15}\end{array}$ & $\begin{array}{c}4^{\text {th }} \text { follow } \\
\operatorname{up}_{26 / 06 / 15}\end{array}$ & $\begin{array}{c}5^{\text {th }} \text { follow } \\
\operatorname{up}_{29 / 06 / 15} \\
* * A T\end{array}$ \\
\hline 1 & Weight (kgs) & 98.1 & $\overline{93.7}$ & 92.5 & 91.1 & 89.3 & 87.9 \\
\hline 2 & $\overline{B M I}\left(\mathrm{~kg} / \mathrm{m}^{2}\right)$ & 33.94 & 32.42 & 32 & 31.52 & 30.89 & 30.41 \\
\hline 3 & Fat Mass (\%) & $\overline{41.3}$ & 41.1 & 41.5 & 36 & 37.8 & 35.4 \\
\hline 4 & Muscle Mass (\%) & 38.4 & 38.5 & 38.5 & 39.9 & 39.5 & 39.3 \\
\hline 5 & Bone Mass (kgs) & 3.3 & $\overline{3.2}$ & 3.2 & 3.2 & 3.2 & 3.2 \\
\hline 6 & Water contain (\%) & 45.1 & $\overline{45.3}$ & 45 & 49 & 47.8 & 48.7 \\
\hline 7 & Waist Girth ( $\mathrm{cm}$ ) & 117 & - & - & - & - & 112 \\
\hline 8 & Hip Girth ( cm ) & 114 & - & - & - & - & 108 \\
\hline
\end{tabular}

*Before Treatment **After Treatment

Table-4: Lipid Profile

\begin{tabular}{|c|c|c|c|}
\hline Sl.No. & Lipid & $\begin{array}{c}\text { Initials (On first visit) } \mathbf{0 5 / 0 6 / 1 5} \\
* \mathbf{B T}(\mathbf{m g} / \mathbf{d l})\end{array}$ & $\begin{array}{c}\mathbf{5}^{\mathrm{th}} \text { follow up 29/06/15 } \\
* * \mathbf{A T}(\mathbf{m g} / \mathbf{d l})\end{array}$ \\
\hline 1 & Serum Cholesterol & 225 & 169 \\
\hline 2 & Serum Triglyceride & 216 & 99 \\
\hline 3 & HDL & 29 & 34 \\
\hline 4 & VLDL & 43.2 & 19.8 \\
\hline 5 & LDL & 152.8 & 115.2 \\
\hline
\end{tabular}

*Before Treatment **After Treatment 


\section{Discussion}

The patient showed very encouraging results just in first follow up. He lost about $10.2 \mathrm{~kg}$. of weight in 26 days and according to fat analyzer it is not water contain which helps in reduced weight but because of the treatment patient saw actually losing weight by reducing fat mass. At last follow up BMI of patient ranged from 33.94 to 30.41 which shows significant decrement and patient reached to lower border of class -2 Obesity. Before treatment waist circumference of patient was 117 $\mathrm{cm}$ and waist / hip circumference was 1.02 which is greater than 0.9. This indicates patient was having central Obesity(5). It was significant improvement in waist circumference from $117 \mathrm{~cm}$ to $112 \mathrm{~cm}$ which shows reduction in abdominal obesity. In all subjective criteria patient showed significant improvement and not only patient feel lightness in body but also is feeling energetic. Orlistat and Sibutramine etc. currently used pharmacological medicines help to lose 5 to $10 \%$ of body weight with long term use but are having Side effect like tachycardia, hypertension, headache and insomnia. While this case shows that Ayurvedic tripod approach (Diet, Exercises and Treatment) to obesity helps to lose more than $10.39 \%$ of body weight and most importantly without any side effect in just 26 days. We found significant decrease in S. cholesterol, $\mathrm{S}$. Triglyceride, LDL and VLDL along with increase in HDL after treatment which has defiantly lower down atherogenicity in patient. We found gradual weight loss and specifically decrement in fat mass throughout treatment. In relation with that hydration and muscle mass of patient were gradually improved. In association with that bone mass mostly remain intact. Overweight / Obesity (BMI of 25 to 30) confers elevated risks of many diseases. For example, overweight people experience a two to threefold elevation in the risks of CAD and hypertension and a more than tenfold increase in the risk of type 2 diabetes compared with lean individuals (BMI less than 23)(6). As patient was having Class - 2 Obesity, waist circumference $117 \mathrm{~cm}$ before treatment, patient was at very high risk of other life style diseases but after treatment patient lost $10.2 \mathrm{~kg}$ of body weight which has defiantly lower down the risk of its morbid consequent pathologies.

All above treatments are fairly mentioned in classical Ayurveda texts:

As per Charaka, Vaman is contraindicated in Ati Sthaulya(7). But being a syndromic condition (Bahu Doshasya Laksanama) Samsodhana therapy is highly recommended for Sthaulya patients possessing stamina \& strength(8). Sushruta has given contraindication of Vamana in Sthaulya, while it is indicated in Medorog(9). All Sthula patients with Adhika Dosha \& Adhika Bala should be treated with Samsodhana Therapy, including Vamana, Virechana, Ruksa Niruha, Raktamoksana \& Sirovirechana(10). So Vamana and Virechana were planned for this patient. Ruksha, Ushna \& Tikshna Basti are also suggested by Acharya Charaka(11) and according to that we have planned Niruha Basti prepared with Trifala Kwatha. Ruksa Udvartana is the Bahya Sodhana indicated for the management of Sthaulya(12). For that we have used Aamalaki and Lodhra choorna. Oral medicines are also mentioned in our texts which are as under.
Arogyavardhini vati(13) :

It is clearly indicated as "Medovinasini" (causing fat loss), "Sarvaroga prasamani" (curing all diseases), it performs all these works in association with Dipan, Pachana karma and impact of pathya and Hridya prabhava. Arogyavardhini vati potentiates the antioxidant activity and shown less degree of carbon tetra chloride inducing hepatic damage. It suppress the formation of free radicals so, might have contributed for antioxidant activity.

\section{Navayasa loha churna (14) :}

Navayasa loha churna described for mainly Pandu, Hridroga, Kushtha, Arsha and Kamala but in Charak samhita santarpaniya adhyaya. Charak described many medications for Sthaulya chikitsa. With that reference most of all drugs are ingredient of Navayasa loha churna, even Pandu and Kustha etc, are Santarpanajanya vyadhi. To have impact on Sthaulya and also preventing measures for other complications it is very useful. In that Trikatu is very effective in $A m a$ Pachana which is prime cause of all the diseases. Triphala is tonic for whole body and also having property of Tridosa Shaman. Motha have property of anti-inflammatory, anti diabetic and anti helminthic effect. It's also has Lekhaniya Pachaniya and Triptighna effect. Vidanga have carminative and hepatoprotective effect. Chitraka reduces vitiated Vata and Kapha.

\section{Varunadi kwatha (15):}

Acharya Susruta has mentioned this Kwatha for Medovaha Srotasa Dushti. They mentioned it as "kapha medo nivarana" and for Shirah shula, Gulma, Abhyantara Vidradhi too. Also it has anti lipidemic and having property of lowering blood glucose level.

\section{Triphala Guggulu (16) :}

Acharya Sharangdhara mentioned this yoga in Bhagandara, Gulma, Shotha and Arsha. It contains triphala, pippali and guggulu. Triphala has known effect of Tridosha shaman. Pippali helps to modulate digestive power even associate with Ama Pachana. Guggulu is Rasayana and Lekhana effect. So, combine all these drugs maintain digestive fire and inhibit Ama production and gradually decreases extra fat from the body.

\section{Conclusion}

At last follow up BMI of patient ranges from 33.94 to 30.41 and weight of patient ranges from 98.1 to $97.9 \mathrm{~kg}$ which shows significant decrement and patient reach to lower border of class -1 obesity. A well integrated Tripod of Diet, Physical exercises and Ayurvedic medicine give excellent results in obesity and other life style diseases. Ayurvedic treatment is more Coast effective as compared to other treatment. Ayurveda can provide not only weight loss but sense of well being and quality life style to obese person. There is no any side effect observed for this Ayurvedic medicine. This case report suggests standard clinical practice guidelines for obesity as black box (Individual) method and gives reference to examine it on research bases by testable hypothesis. 


\section{References}

1. WHO 2000 p.6

2. Barness LA, Opitz JM, Gilbert-Barness E (December 2007). "Obesity: genetic, molecular, and environmental aspects". American Journal of Medical Genetics 143A (24): 3016-34. doi:10.1002/ ajmg.a.32035. PMID 18000969.

3. Haslam DW, James WP (2005). "Obesity". Lancet (Review) 366 (9492): 1197-209. doi:10.1016/S0140 -6736(05)67483-1. PMID 16198769.

4. World Health Organization (2000). Obesity: preventing and managing the global epidemic (Report). World Health Organization. pp. 1-2. Retrieved 1 February 2014.

5. National Cholesterol Education Program (2002). Third Report of the Expert Panel on Detection, Evaluation, and Treatment of High Blood Cholesterol in Adults (ATP III Final Report). National Institutes of Health. p. II-17.

6. Willett, Dietz, and Colditz 1999 - edited by Dean T. Jamison, Joel G. Breman, Anthony R. Measham, George Alleyne, Mariam Claeson, David B. Evans, Prabhat Jha, Anne Mills, Philip Musgrove "Disease Control Priorities in Developing Countries".

7. Vaidya yadavji Trikamaji Aacharya, Charaka Sanhita, Kalpa Sthana, $2^{\text {th }}$ chapter, $8^{\text {th }}$ sloka. P 689.
8. Vaidya yadavji Trikamaji Aacharya, Charaka Sanhita, Sutra Sthana, $16^{\text {th }}$ chapter, $13^{\text {th }}$ sloka. P 97.

9. Vaidya yadavji Trikamaji Aacharya and Narayana Ram Aacharya, Sushruta Sanhita, Chikitsa sthana, $33^{\text {ed }}$ chapter, $14^{\text {th }}-18^{\text {th }}$ sloka, p 517 .

10. Yadunandana Upadhyaya, Ashtanga Hradayama, Sutra Sthana, $14^{\text {th }}$ chapter, $12^{\text {th }}$ sloka. P 136.

11. Vaidya yadavji Trikamaji Aacharya, Charaka Sanhita, Sutra Sthana, $21^{\text {th }}$ chapter, $21^{\text {th }}-23^{\text {th }}$ sloka. P 117.

12. Vaidya yadavji Trikamaji Aacharya, Charaka Sanhita, Sutra Sthana, $21^{\text {th }}$ chapter, $21^{\text {th }}-23^{\text {th }}$ sloka. P 117.

13. Ambikadatta shastri Rasaratna Samuchchya $20^{\text {th }}$ chapter $87^{\text {th }}$ shloka. $9^{\text {th }}$ edition; 1994. P.400.

14. Govindadas. Bhaishajya Ratnavali.Ambikadatta Shastri, Vidyotini vyakhya. In:Rajeshwardatta Shastri, $\quad$ editor.Chapter $12^{\text {th }}$, Verse 28,18 ${ }^{\text {th }}$ ed.Varanasi: Chaukhamba Sanskrit Sansthan;2005.P.378

15. Shushrut Ayurved translated by Shashtri Kalidas Govindaji Third Edition, part 1 Sootrasthan adhyay $38 / 5$, Sastu sahitya vardhak karyalaya, page 210 .

16. Sharangdharacharya virachita sharangdhara samhita dipika hindi vyakhya teeka by Brahmananda tripathi, Chaukhambha surbharati prakashaana, Madhyam khanda, Vatak kalpana, P 206. 